\title{
Selectivity of Insecticides Against Telenomus podisi Ashmead (Hymenoptera: Platygastridae) on Corn
}

\author{
Elidiane Feltrin-Campos ${ }^{1}$, Marcos Gino Fernandes ${ }^{1}$, Gabrielle de Lima Masson ${ }^{1}$, Thaís Araujo Corrêa ${ }^{1}$ \\ \& José Fernando Jurca Grigolli ${ }^{2}$ \\ ${ }^{1}$ Federal University of Grande Dourados, Dourados, MS, Brazil \\ ${ }^{2}$ Fundação MS, Maracaju, MS, Brazil \\ Correspondence: Elidiane Feltrin-Campos, Federal University of Grande Dourados, MS, Brazil. Tel: \\ 55-67-99830-8439. E-mail: elidifeltrin@hotmail.com
}

Received: July 20, $2018 \quad$ Accepted: September 17, $2018 \quad$ Online Published: November 15, 2018

doi:10.5539/jas.v10n12p185 URL: https://doi.org/10.5539/jas.v10n12p185

\begin{abstract}
Use of synthetic insecticides remains main control strategy for percevejo-marrom (Euschistus heros) in corn. However, indiscriminate use of these products can have adverse effects on the environment and human health. Thus, incorporation of bio-agents like Telenomus podisi a preferred option in corn pest management. Study was conductedto evaluate the effects of insecticides application on $T$. podisi mortality rates, the number of eggs parasitized by the $F_{0}$ generation, and number of emergent $F_{1}$ parasitoids. The insecticides tested were: imidacloprid+bifenthrin, bifenthrin+carbosulfan, thiametoxam+lambda-cyhalothrin, acephate, bifenthrin, and imidacloprid at the highest concentrations indicated for corn. Each insecticide was classified according to its selectivity, based on the methodology proposed by IOBC/WPRS. Only imidacloprid did not affect parasitoid survival however the parasitism rates of $\mathrm{F}_{0}$ females, were affected, classifying this product as slightly harmful for this biological trait. Regarding parasitoid emergence $\left(\mathrm{F}_{1}\right)$, thiametoxam+lambda-cyhalothrin was classified as moderately harmful, while bifenthrin+carbosulfan and bifenthrin were considered harmful, no parasitism occurred. Thus the evaluated insecticides were classified as slightly harmful to the parasitoid T. podisi under laboratory conditions for the biological characteristics evaluated. Further studies under semi-field and field conditions are needed in order to confirm these toxicity levels on T. podisi.
\end{abstract}

Keywords: integrated pest management, biological control, parasitoids

\section{Introduction}

Corn Zea mays L., is a grain of great economic importance in Brazil.It is wider in use at processing industry where it is processed into a wide range of products including livestock feed as well as in the high technology industry Ministério da Agricultura, Pecuária e Abastecimento (MAPA, 2012). However, this crop is attacked by insect pests that can cause extensive crop losses to farmers (Grigolli \& Lourenção, 2013).

Among these insect pests, the Neotropical brown stinkbug, Euschistus heros (Fabricius, 1798), has become economically important (Quintela, Ferreira, Guimarães, L. F. C. de Oliveira, A. C. Oliveira, \& Czepak, 2006), due to its adverse economic impacts that include stunted growth, unproductive plants, and lower yields (Jandrey, 2014; Viana, 2016).

Recently the economic impact of sucking insect pests in corn has become more pronounced, as reflected in a $65 \%$ increase in corn fields requiring/reporting treatment in 2015 season. The average cost of field applications rose from $\mathrm{R} \$ 22$ to 26 per hectare, because farmers made more applications to control sucking insects and dded more products to spray treatments: $11 \%$ of the treatments combined two insecticide products and $96 \%$ of the treated areas received two specific applications for stinkbugs (Kleffmann Group, 2016).

Chemical control is the most used method against sucking insects in corn because it is practical and effective, but it has adverse effects on humans, animals, and the environment (Mendes, Boregas, Lopes, Waquil, \& Waquil, 2011). Thus other methods have been used, such as biological control with egg parasitoids, Telenomus sp. Theses parasitoids have the advantage of controlling the pest before damage to the crop occurs (Parra, Botelho, Correa, \& Bento, 2002), and Telenomus podisi Ashmead was considered the main factor affecting the mortality of $E$. heros under field conditions (Godoy, Galli, \& Ávila, 2005). However, the use of non-selective chemicals 
adversely affect natural enemies and reduce the effectiveness of biological control. Several studies have shown adverse effects of chemicals on Telenomus remus (Carmo, A. F. Bueno, R. C. O. F. Bueno, Vieira, Gobbi, \& Vasco, 2009; Vieira, Boff, A. F. Bueno, Gobbi, Lobo, \& R. C. O. F. Bueno, 2012), Trissolcus sp., (González, Laumann, Silveira, Moraes, Borges, \& Ferreira, 2013), Trichogramma galloi (Oliveira, Antigo, Carvalho, Glaeser \& Pereira, 2013), Telenomus podisi (Smaniotto, Gouvea, Potrich, E. R. L. Silva, J. Silva \& Pegorini, 2013; Turchen, Golin, Butnariu, Guedes, \& Pereira, 2015; Pazini, Pasini, Seidel, Rakes, Martins, \& Grutzmacher, 2017), among other egg parasitoids.

The goal of an Integrated Pest Management (IPM) program is to combine control methods that complement and do not adversely affect each other. Therefore, it is important to test the selectivity of several pesticides that can be used with some natural enemies in IPM programs. Studies have shown that chlorantraniliprole and M. anisopliae are not harmful (class 1) to $T$. galloi adults, since they do not affect the survival, parasitism, or emergence of this parasitoid, making it possible to use them in combination with insecticides (Oliveira et al, 2013).

Similarly, the abundance of Chrysodeixis includens Walker (Lepidoptera: Noctuidae) is lower in soybean treated with Baculovirus anticarsia (AgMNPV), because this microbial control agent does not adversely affect biological control agents (Corrêa-Ferreira, Alexandre, Pellizzaro, Moscardi, \& Bueno, 2010). In contrast, chemical insecticides, due to their harmful effects on natural enemies, have been shown to increase the number of C. includens larvae (Bueno, Carvalho, Santos, Sosa-Gómez, \& Silva, 2017). Therefore, parasitoids, entomopathogens, and chemicals can be used simultaneously, but compatibility needs to be evaluated (Polanczyk, Pratissoli, Dalvi, Grecco \& Franco, 2010; Oliveira et al, 2013).

Most studies regarding toxicity on egg parasitoids are focused on lepidopteran insects (Carmo, A. F. Bueno, \& R. C. O. F. Bueno, 2010; Oliveira et al., 2013; Golin, 2014), while few toxicological studies target pentatomids. Thus studies including other orders of insects are needed. This study was aimed at evaluating the selectivity of chemical products used in corn to control E. heros for the egg parasitoid T. podisi.

\section{Material and Methods}

Bioassays to evaluate of the selectivity of products for the parasitoid Telenomus podisi were carried out at the Laboratory of Entomology of the Federal University of Grande Dourados, Dourados-MS, Brasil. All tests were performed and maintained in a climate chamber at $25 \pm 2{ }^{\circ} \mathrm{C}, 60 \pm 10 \% \mathrm{RH}$, and 12-hour (L:D) photophase. The products tested were commercial formulations of the insecticides imidacloprid+bifenthrin $(400 \mathrm{~mL} / \mathrm{ha})$, bifenthrin+carbosulfan $(500 \mathrm{~mL} / \mathrm{ha})$, thiamethoxam+lambda-cyhalothrin $(250 \mathrm{~mL} / \mathrm{ha})$, acephate $(800 \mathrm{~g} / \mathrm{ha})$, bifenthrin $(300 \mathrm{~mL} / \mathrm{ha})$, imidacloprid $(250 \mathrm{~mL} / \mathrm{ha})$, as they are the most commonly used to control E. heros in corn in Brazil. Distilled water was used as a control.

\subsection{Bioassay I: Assessment of Adult Mortality}

A day old twenty $T$. podisi females were individually maintained in glass tubes $(10 \times 90 \mathrm{~mm})$ and fed with droplet of pure honey placed on the inner wall of the tube, that was sealed with PVC film perforated with an entomological pin for aeration. Subsequently, rectangles of blue card stock paper $(1.0 \times 3.0 \mathrm{~cm})$, each containing 50 eggs of E. heros attached with $10 \%$ gum arabic, were immersed for five seconds in a solution of one of the chemical products tested (Good et al, 2008). Card stock rectangles were then removed from the bath and allowed to dry on paper towel at room temperature for one hour to remove the excess liquid. The eggs were then exposed for 24 hours to individual females in the tubes, in order to evaluate the selectivity of the insecticides for adult parasitoids.

\subsection{Bioassay II: Assessment of Parasitism}

To assess egg parasitism rates, eggs were treated with the test insecticides, twenty card stock rectangles with eggs were individually placed in a glass tube with one T. podisi female, as proposed by Brugger et al. (2010) and Vianna et al. (2009). Parasitism rates (number of eggs parasitized by females for 24 hours) were calculated.

\subsection{Bioassay III: Adult Emergence in Insecticide-Treated Eggs}

In order to examine possible effects of insecticide-treated eggs on the larval development and emergence rate of the parasitoid was calculated (number of eggs with exit holes of the parasitoid/total number of parasitized eggs) $\times 100]$ based on twenty replicates, following the methodology described in the previous bioassay. 


\subsection{Statistical Analysis and Classification of Insecticides}

The experimental design was randomized with seven treatments (six insecticides and one control group). Each treatment consisted of 20 replicates (each replicate composed of a card stock paper with 50 E. heros eggs). The groups were compared with an analysis of variance and the Tukey test with a level of significance of $1 \%$.

According to recommendations of the International Organization for Biological and Integrated Control (IOBC), the tested insecticides were also classified into toxicological classes based to the percentage of reduction (PR) of the parasitoid's beneficial capacities (mortality, parasitism, and emergency) compared to the control group, calculated as : $\mathrm{PR}=[100-(\%$ overall mean of insecticide treatment/general mean of control group $)] \times 100$.

In accord with IOBC recommendations, the tested insecticides were classified by the percentage reduction (PR) of parasitoid beneficial abilities (survival, parasitism, and emergence) in relation to the control treatment: class 1 $=$ innocuous, reduction less than $30 \%$; class $2=$ slightly harmful, $30-79 \%$; class $3=$ moderately harmful, $80-99 \%$; and class $4=$ harmful, $>99 \%$ (Sterk et al., 1999).

\section{Results}

\subsection{Bioassay I}

The mortality rates of $T$. podisi $\left(\mathrm{F}_{0}\right)$ females that were in contact with $E$. heros eggs treated with the insecticides thiametoxam+lambda-cyhalothrin, bifenthrin, imidacloprid+bifenthrin, bifenthrin+carbosulfan, and acephate were statistically higher when compared to imidacloprid and the control group. According to the reduction in mortality, the treatment with thiametoxam+lambda-cyhalothrin was classified as moderately harmful (Class 3), while bifenthrin, imidacloprid+bifenthrin, bifenthrin+carbosulfan and acephate were slightly harmful (Class 2). Imidacloprid was classified as innocuous (Class 1), thus not reducing the survival of T. podisi (Table 1).

Table 1. Mortality (\%) ( \pm SD), percentage of reduction (PR) and toxicological class of Telenomus podisi in eggs of Euschistus heros treated with corn insecticides in a selectivity test. Means followed by the same lowercase letter in the column do not differ by Tukey $(\mathrm{p}>0.05)$

\begin{tabular}{lllll}
\hline Treatments & Commercial Product Dose (P.C) & Mortality (\%) & PR $^{\mathbf{1}}$ (\%) & Class $^{\mathbf{2}}$ \\
\hline Control & - & $0.00 \pm 0.00 \mathrm{c}$ & - & - \\
Imidacloprid+Bifentrina & $400 \mathrm{~mL} / \mathrm{ha}$ & $65.0 \pm 0.10 \mathrm{a}$ & 65.0 & 2 \\
Bifentrina+Carbosulfano & $500 \mathrm{~mL} / \mathrm{ha}$ & $60.0 \pm 0.11 \mathrm{a}$ & 60.0 & 2 \\
Thiamethoxam+Lambda-Cialotrina & $250 \mathrm{~mL} / \mathrm{ha}$ & $80.00 \pm 0.11 \mathrm{a}$ & 80.00 & 3 \\
Acefato & $800 \mathrm{~g} / \mathrm{ha}$ & $55.0 \pm 0.09 \mathrm{ab}$ & 55.0 & 2 \\
Bifentrina & $300 \mathrm{~L} / \mathrm{ha}$ & $75.00 \pm 0.09 \mathrm{a}$ & 75.0 & 2 \\
Imidacloprid & $250 \mathrm{~mL} / \mathrm{ha}$ & $15.0 \pm 0.08 \mathrm{c}$ & 15.0 & 1 \\
\hline
\end{tabular}

Note. ${ }^{1}$ Average percentage of parasitism reduction in T. podisi. ${ }^{2}$ Toxicity classes recommended by Sterk et al. (1999).

\subsection{Bioassay II}

Regarding the number of parasitized eggs of T. podisi on E. heros eggs treated with insecticides, among the six products tested, only acephate (reduction of parasitism rate of $67.08 \%$ ) and imidacloprid (reduction of parasitism rate of $32.01 \%$ ) were classified as slightly harmful (Class 2 ). The insecticides thiametoxam+lambda-cyhalothrin (reduced parasitism by $97.55 \%$ ) and imidacloprid+bifenthrin (reduced parasitism by $95.56 \%$ ) were classified as moderately harmful, while bifenthrin and bifenthrin+carbosulfan (reduced parasitism in more than 99\%) were classified as harmful (Table 2). 
Table 2. Number ( \pm EP) of parasitized eggs and percentage of reduction (PR) of Telenomus podisi in eggs of Euschistus heros treated with corn insecticides in a selectivity test. Means followed by the same lowercase letter in the column do not differ by Tukey ( $p>0.05)$

\begin{tabular}{|c|c|c|c|c|c|}
\hline Treatments & $\begin{array}{l}\text { Commercial } \\
\text { Product Dose (P.C) }\end{array}$ & $\begin{array}{l}\text { Mean number of } \\
\text { eggs parasitized by } \\
\text { T. podisi }(\mathrm{n}=\mathbf{5 0 *})\end{array}$ & $\begin{array}{l}\% \text { eggs parasitized } \\
\text { of } T \text {. podisi }\end{array}$ & $\mathrm{PR}^{1}(\%)$ & Class $^{2}$ \\
\hline Control & - & $32.65 \pm 1.49 \mathrm{a}$ & 65.30 & - & - \\
\hline Imidacloprid + Bifentrina & $400 \mathrm{~mL} / \mathrm{ha}$ & $1.45 \pm 0.35 \mathrm{~d}$ & 4.00 & 95.56 & 3 \\
\hline Bifentrina + Carbosulfano & $500 \mathrm{~mL} / \mathrm{ha}$ & $0.15 \pm 0.08 \mathrm{~d}$ & 2.00 & 99.55 & 4 \\
\hline Thiamethoxam+Lambda-Cialotrina & $250 \mathrm{~mL} / \mathrm{ha}$ & $0.80 \pm 0.17 \mathrm{~d}$ & 2.00 & 97.55 & 3 \\
\hline Acefato & $800 \mathrm{~g} / \mathrm{ha}$ & $10.75 \pm 0.75 \mathrm{c}$ & 21.50 & 67.08 & 2 \\
\hline Bifentrina & $300 \mathrm{~L} / \mathrm{ha}$ & $0.10 \pm 0.06 \mathrm{~d}$ & 2.00 & 99.70 & 4 \\
\hline Imidacloprid & $250 \mathrm{~mL} / \mathrm{ha}$ & $22.20 \pm 2.53 \mathrm{~b}$ & 44.40 & 32.01 & 2 \\
\hline
\end{tabular}

Note. ${ }^{*}$ Mean number the parasitized eggs based on total number of eggs per replicate (50 eggs repetition). ${ }^{1}$ Mean percentage of parasitismo reduction in T. podisi. ${ }^{2}$ Toxicity classes recommended by Sterk et al. (1999).

\subsection{Bioassay III}

The emergence rates of $T$. podisi $\left(\mathrm{F}_{1}\right)$ from E. heros eggs treated with imidacloprid+bifenthrin, acephate, and imidacloprid were not affected, when compared to the control group and the insecticides were classified as innocuous (Class 1) for this trait. Only bifenthrin+carbosulfan and bifenthrin had adverse effects (Class 4), as they reduced parasitoid emergence by more than $99 \%$ (Table 3 ).

Table 3. Emergence ( \pm EP) and percentage of reduction (PR) of Telenomus podisi in eggs of Euschistus heros treated with corn insecticides in a selectivity test. Means followed by the same lowercase letter in the column do not differ by Tukey $(\mathrm{p}>0.05)$

\begin{tabular}{llllc}
\hline Treatments & Commercial Product Dose (P.C) & \% of emergency T. podisi & PR $^{\mathbf{1}}(\%)$ & Class $^{\mathbf{2}}$ \\
\hline Control & - & $87.05 \pm 0.02 \mathrm{a}$ & - & - \\
Imidacloprid+Bifentrina & $400 \mathrm{~mL} / \mathrm{ha}$ & $65.30 \pm 0.11 \mathrm{a}$ & 24.99 & 1 \\
Bifentrina+Carbosulfano & $500 \mathrm{~mL} / \mathrm{ha}$ & $0.00 \pm 0.00 \mathrm{~b}$ & - & 4 \\
Thiamethoxam+Lambda-Cialotrina & $250 \mathrm{~mL} / \mathrm{ha}$ & $10.25 \pm 0.07 \mathrm{~b}$ & 88.25 & 3 \\
Acefato & $800 \mathrm{~g} / \mathrm{ha}$ & $82.40 \pm 0.03 \mathrm{a}$ & 5.35 & 1 \\
Bifentrina & $300 \mathrm{~L} / \mathrm{ha}$ & $0.00 \pm 0.00 \mathrm{~b}$ & - & 4 \\
Imidacloprid & $250 \mathrm{~mL} / \mathrm{ha}$ & $80.05 \pm 0.04 \mathrm{a}$ & 8.05 & 1 \\
\hline
\end{tabular}

Note. ${ }^{1}$ Mean percentage reduction in the emergence of T. podisi. ${ }^{2}$ Toxicity classes recommended by Sterk et al. (1999).

\section{Discussion}

Contact with eggs treated with thiamethoxam+lambda-cyhalothrin resulted in a mortality rate of $80 \%$ in $T$. podisi females. This insecticide belongs to the neonicotinoid+pyrethroid chemical group and these active ingredients are not very selective (Cañete, 2005; Lim \& Mahmoud, 2008; Koppel, Herbert, Kuhar, Malone, \& Arrigton, 2011). Treatment with this same chemical resulted in mortality rates up to $100 \%$ in $T$. podisi Turchen et al. (2015).

Rapid death and high mortality rates are generally expected when using neurotoxic insecticides, based on their mode of action. For example, pyrethroids are sodium channel blockers acting on axonal neurotransmission, whereas neonicotinoids are agonists of different subtypes of nicotinic acetylcholine receptors in the synapses of the insect central nervous system (Casida \& Durkin, 2013; Turchen et al., 2015). This also explains the results obtained for insecticides of the same chemical group imidacloprid+bifenthrin, bifenthrin and bifenthrin+carbosulfan, which were classified as slightly harmful to the survival of $T$. podisi.

The acephate-based insecticide was also detrimental to the survival of $T$. podisi, as it belongs to the organophosphorus chemical group, and affects insects mainly by phosphorylating the enzyme acetylcholinesterase (AChE). This results in loss of available AChE and organ overstimulation due to excess 
acetylcholine in nerve endings, affecting natural enemies and pests in a similar way. This insecticide is available on the market at more accessible prices to farmers who often overuse it (Carmo et al., 2010). However according to our findings, this product is not compatible with biological control practices.

Bifenthrin+carbosulfan and bifenthrin-based insecticides of the pyrethroid and benzofuranyl methylcarbamate groups reduced parasitism and emergence rates of $T$. podisi, as also reported for the parasitoids $T$. remus (Carmo et al., 2010) and T. pretiosum (Pinto, Magano, Pasini, Spagnol, Anjos, \& Grutzmacher, 2012).

The insecticides acephate (organophosphate) and imidacloprid (neonicotinoid) act by contact and ingestion, disorganizing the nervous system of insects (Carmo et al., 2009). The effects of these insecticides on parasitism rates in the present study were classified as slightly harmful (Class 2), which may be associated to its mode of action, thus preventing a high rate of parasitism by parasitoids. On the other hand, when parasitoid emergence was evaluated, no harmful effects were observed (Class 1). Similar results were obtained for T. pretiosum (Carvalho, Fuini, Rocha, Reis, Moraes, \& Ecole, 2003; A. F. Bueno, R. C. O. F. Bueno, Parra, \& Vieira, 2008), T. remus (Carmo et al., 2010), and T. podisi (Turchen et al., 2015). However, this same product, used in the same dosage of this study, can vary from harmless to harmful, depending on the developmental stage of the natural enemy (Souza, Carvalho, Moura, Couto \& Maia, 2014). Parasitoid pupae and larvae might be more resistant to pesticides, compared to adults, because they develop inside the host egg, which is protected against insecticides by the chorion (Stecca, Bueno, Pasini, Silva, Andrade, \& Filho, 2016).

The results obtained for the pesticides imidacloprid+bifenthrin and thiametoxam+lambda-cyhalothrin were considered moderately harmful. Other recent studies also reported similar results (Turchen et al., 2015).

In contrast, only bifenthrin+carbosulfan and bifenthrin adversely affected the emergence of parasitoids (Table 3). Similar results were found for bifenthrin on the emergence of T. remus (Carmo et al., 2010). These results are expected, since these insecticides are more likely to affect parasitism rates than emergence, as they do not appear to interfere in the development of larvae and pupae of the parasitoid inside the host egg, due to the protection provided by the chorion (Carmo et al., 2009; Turchen, Golin, Butnariu, \& Pereira, 2014; Turchen et al., 2015).

Regardless of the evaluated biological characteristics of the parasitoid, our findings indicated that the insecticides with more than one active ingredient had the most harmful effects on T. podisi parasitoids. Among the insecticides used with these characteristics are: thiametoxam+lambda-cyhalothrin (neonicotinoid+pyrethroid), bifenthrin+imidacloprid (pyrethroid+neonicotinoid), and bifenthrin+carbosulfan (pyrethroid+benzofuranil methylcarbamate).

\section{References}

Brugger, K. E., Cole, P. G., Newman, I. C., Parker, N., Scholz, B., Suvagia, P., ... Hammond, T. (2010). Selectivity of chlorantraniliprole to parasitoid wasps. Pest Manag. Sci., 6, 1075-1081. https://doi.org/ 10.1002/ps.1977

Bueno, A. F., Bueno, R. C. O. F., Parra, J. R. P., \& Vieira, S. S. (2008). Effects of pesticides used in soybean crops to the egg parasitoid Trichogramma pretiosum. Ciência Rural, 38, 1495-1503. https://doi.org/ $10.1590 / \mathrm{S} 0103-84782008000600001$

Bueno, A. F., Carvalho, G. A., Santos, A. C., Sosa-Gómez, D. R., \& Silva, D. M. (2017). Pesticide selectivity to natural enemies: Challenges and constraints for research and field recommendation. Ciência Rural, 47, 1-10. https://doi.org/10.1590/0103-8478cr20160829

Carmo, E. L., Bueno, A. F., \& Bueno, R. C. O. F. (2010). Pesticide selectivity for the insect egg parasitoid Telenomus remus. BioControl, 55, 455-464. https://doi.org/10.1007/s10526-010-9269-y

Carmo, E. L., Bueno, A. F., Bueno, R. C. O. F., Vieira, S. S., Gobbi, A. L., \& Vasco, F. R. (2009). Seletividade de diferentes agrotóxicos usados na cultura da soja ao parasitoide de ovos Telenomus remus. Ciência Rural, 39, 2293-2300. https://doi.org/10.1590/S0103-84782009005000188

Carvalho, G. A., Fuini, L. C., Rocha, L. C. D., Reis, P. R., Moraes, J. C., \& Ecole, C. C. (2003). Avaliação da seletividade de inseticidas utilizados na tomaticultura a Trichogramma pretiosum Riley (Hymenoptera: Trichogrammatidae). Rev. Ecossistema, 28.

Casida, J. E., \& Durkin, K. A. (2013). Neuroactive insecticides: Targets, selectivity, resistance, and secondary effects. Annu. Rev. Entomol., 58, 99-117. https://doi.org/10.1146/annurev-ento-120811-153645

Corrêa-Ferreira, B. S., Alexandre, T. M., Pellizzaro, E. C., Moscardi, F., \& Bueno, A. F. (2010). Pest management practices used in soybean and their impact on the crop (Circular Técnica, 78, p. 15). Londrina: Embrapa Soja. 
Godoy, K. B., Galli, J. C., \& Ávila, C. J. (2005). Parasitismo em ovos de percevejos da soja Euschistus heros (Fabricius) e Piezodorus guildinii (Westwood) (Hemiptera: Pentatomidae) em São Gabriel do Oeste, MS. Ciência Rural, 35(2), 455-458. https://doi.org/10.1590/S0103-84782005000200034

González, W. J. O., Laumann, R. A., Silveira, S., Moraes, M. C. B., Borges, M., \& Ferrero, A. A. (2013). Lethal and sublethal effects of four essential oils on the egg parasitoids Trissolcus basalis. Chemosphere, 92(5), 608-615. https://doi.org/10.1016/j.chemosphere.2013.03.066

Grigolli, J. F. J., \& Lourenção, A. L. F. (2013). Pragas do milho safrinha. In R. Roscoe, A. L. F. Lourenção, J. F. J. Grigolli, A. M. Melotto, C. Pitol, \& A, R. A. S. Mirand (Eds.), Tecnologia e Produção: Milho Safrinha e Culturas de Inverno (1st ed., pp. 102-120). Curitiba: Midiograf.

Jandrey, D. (2014). Manejo de milho para altos rendimentos. Artigos, DuPont Pioneer.

KLFF (Kleffmann Group). (2016). Exclusivo: Relatório de fechamento Milho Safrinha. Painel AMIS CPP milho safrinha 2015. Retrieved from http://www.portalklff.com.br/publicacao/exclusivo-relatorio-de-fechamentomilho-safrinha-1245

Koppel, A. L., Herbert, Jr. D. A., Kuhar, T. P., Malone, S., \& Arrington, M. (2011). Efficacy of Selected Insecticides Against Eggs of Euschistus servus and Acrosternum hilare (Hemiptera: Pentatomidae) and the Egg Parasitoid Telenomus podisi (Hymenoptera: Scelionidae). Journal of Economic Entomology, 104, 137-142. https://doi.org/10.1603/EC10222

Lim, U. T., \& Mahmoud, A. M. A. (2008). Ecotoxicological effect of fenitrothion on Trissolcus nigripedius (Hymenoptera: Scelionidae) an egg parasitoid of Dolycoris baccarum (Hemiptera: Pentatomidae). J. Asia Pac. Entomol., 11, 207-210. https://doi.org/10.1016/j.aspen.2008.09.004

MAPA (Ministério da Agricultura). (2012). Vegetal-Culturas-Milho. Retrieved from http://www.agricultura. gov.br/vegetal/culturas/milho

Mendes, S. M., Boregas, K. G., Lopes, M. E., Waquil, M. S., \& Waquil, J. M. (2011). Respostas da lagarta-do-cartucho a milho geneticamente modificado expressando a toxina Cry $1 \mathrm{~A}(\mathrm{~b})$. Pesq. Agropec. Bras, Brasilia, 46(3), 239-244. https://doi.org/10.1590/S0100-204X2011000300003

Oliveira, H. N., Antigo, M. R., Carvalho, G. A., Glaeser, D. F., \& Pereira, F. F. (2013). Seletividade de inseticidas utilizados na cana-de-açúcar a adultos de Trichogramma galloi Zucchi (Hymenoptera: Trichogrammatidae). Bioscience Journal, 29, 1267-1274.

Parra, J. R. P., Botelho, P. S. M., Corrêa, F. B. S., \& Bento, J. M. S. (2002). Controle Biológico no Brasil: Parasitoides e predadores. São Paulo: Manole.

Pazini, J. B., Pasini, R. A., Seidel, E. J., Rakes, M., Martins, J. F. S., \& Grutzmacher, A. D. (2017). Side-effects of pesticides used in irrigated rice areas on Telenomus podisi Ashmead (Hymenoptera: Platygastridae). Ecotoxicology, 26, 782-791. https://doi.org/10.1007/s10646-017-1809-0

Pinto, C. C., Magano, D. A., Pasini, R. A., Spagnol, D., Anjos, R. R., \& Grutzmacher, A. D. (2012). Seletividade de inseticidas neurotóxicos e reguladores de crescimento de insetos registrados para a cultura da soja a adultos de Trichogramma pretiosum Riley, 1879 (Hymenoptera: Trichogrammatidae). XIV ENPOS, Pelotas-RS.

Polanczyk, R. A., Pratissoli, D., Dalvi, L. P., Grecco, E. D., \& FrancO, C. R. (2010). Efeito de Beauveria bassiana (Bals.) Vuillemin e Metarhizium anisopliae (Metsch.) Sorokin nos parâmetros biológicos de Trichogramma atopovirilia Oatman \& Platner, 1983 (Hymenoptera: Trichogrammatidae). Ciênc. Agrotec, 34, 1412-1416. https://doi.org/10.1590/S1413-70542010000600008

Quintela, E. D., Ferreira, S. B., Guimarães, W. F. F., Oliveira, L. F. C. De., Oliveira, A. C., \& Czepak, C. (2006). Desafios do MIP em soja em grandes propriedades no Brasil Central (pp. 127-133). Congresso Brasileiro De Soja, 4, Londrina. Anais... Londrina: Embrapa Soja.

Smaniotto, L. F., Gouvea, A., Potrich, M., Silva, E. R. L., Silva, J., \& Pegorini, C. S. (2013). Seletividade de produtos alternativos a Telenomus podisi Ashmead (Hymenoptera: Scelionidae). Semina, 34, 3295-3306.

Souza, J. R., Carvalho, G. A., Moura, A. P., Couto, M. H. G., \& Maia, J. B. (2014). Toxicity of some insecticides used in maize crop on Trichogramma pretiosum (Hymenoptera, Trichogrammatidae) immature stages. Chilean Journal of Agriccultural Research, 74, 234-239. https://doi.org/10.4067/S0718-583920140002 00016 
Stecca, C. S., Bueno, A. F., Pasini, A., Silva, D. M., Andrade, K., \& Filho, D. M. Z. (2016). Side-effects of glyphosate to the parasitoid Telenomus remus Nixon (Hymenoptera: Platygastridae). Neotropical Entomology, 45(2), 192-200. https://doi.org/10.1007/s13744-016-0363-4

Turchen, L. M., Golin, V., Butnariu, A. R., \& Pereira, M. J. B. (2014). Selectivity of Annona (Annonaceae) extract on egg parasitoid Trissolcus urichi Crawford, 1913 (Hymenoptera: Platygastridae). Rev. Colomb. Entomol, 40, 176-180.

Turchen, L. M., Golin, V., Butnariu, A. R., Guedes, R. N. C., \& Pereira, M. J. B. (2015). Lethal and Sublethal Effects of Insecticides on the Egg Parasitoid Telenomus podisi (Hymenoptera: Platygastridae). Journal of Economic Entomology, 109, 84-92. https://doi.org/10.1093/jee/tov273

Viana, F. F. (2016). Pragas Secundárias do Milho Safrinha. Retrieved from http://www.pioneersementes.com.br/ blog/85/pragas-secundarias-do-milho-safrinha

Vianna, U. R., Pratissoli, D., Zanuncio, J. C., Lima, E. R., Brunner, J., Pereira, F. F., \& Serrão, J. E. (2009). Insecticide toxicity to Trichogramma pretiosum (Hymenoptera: Trichogrammatidae) females and effect on descendant generation. Ecotoxicology, 18, 180-186. https://doi.org/10.1007/s10646-008-0270-5

Vieira, S. S., Boff, M. I. C., Bueno, A. F., Gobbi, A. L., Lobo, R. V., \& Bueno, R. C. O. F. (2012). Efeitos dos inseticidas utilizados no controle de Bemisia tabaci (Gennadius) biótipo B e sua seletividade aos inimigos naturais na cultura da soja. Semina: Ciências Agrárias, 33(5), 1809-1818. https://doi.org/10.5433/ 1679-0359.2012v33n5p1809

\section{Copyrights}

Copyright for this article is retained by the author(s), with first publication rights granted to the journal.

This is an open-access article distributed under the terms and conditions of the Creative Commons Attribution license (http://creativecommons.org/licenses/by/4.0/). 